\title{
Study of Structure-Properties Relationship for Lanthanide Tetrapyrrolic Macrocycles Modified with Aminopolycarboxylate Substituents
}

\author{
Nikolay N. Semenishyn and Natalia V. Rusakova ${ }^{\circledR}$ \\ A. V. Bogatsky Physico-Chemical Institute, 65080 Odessa, Ukraine \\ ${ }^{\circledR}$ Corresponding authorE-mail: lanthachem@ukr.net
}

\begin{abstract}
The structure of lanthanide complexes based on ditopic corroles and porphyrins is studied in details. Fluorescence and 4 -luminescence features of corrole-based and porphyrin-based lanthanide systems are compared. It was found out, that porphyrin derivatives have three types of emission (fluorescence, phosphorescence and $4 f$-luminescence) in two ranges (visual and near infrared) and corrole derivatives have two types of emission (fluorescence and 4 -luminescence) in two ranges (visual and near infrared). It is shown that sensitization mechanism of luminescence of $\mathrm{Nd}$ and $\mathrm{Yb}$ ions has different pathways in corroles.
\end{abstract}

Keywords: Corroles, porphyrins, lanthanides, $4 f$-luminescence, fluorescence.

\section{Изучение связи структура-свойства в комплексах лантанидов с тетрапиррольными макроциклами, модифицированными аминополикарбоксилатными заместителями}

\author{
Н. Н. Семенишин, Н. В. Русакова ${ }^{\circledR}$ \\ Физико-химический институт им. А.В. Богатского, 65080 Одесса, Украина \\ ${ }^{\circledR}$ E-mail: lanthachem@ukr.net
}

\begin{abstract}
В работе проведен синтез периферических комплексов лантанидов с порфиринами и корролами и проведено детальное исследование их структуры. Проведено сравнение флуоресцентных и 4f-люминесиентных свойств данных соединений. Показано, что для периферических комплексов лантанидов с порфиринами характерно наличие трёх видов эмиссии (флуоресценция, фосфоресценция и 4f-люминесценция), а для периферических комплексов лантанидов с корролами характерно наличие двух видов эмиссии (флуоресценция u 4f-люминесценция), причём флуоресценциия макроцикла остаётся непогашенной в обоих случаях. Механизм сенсибилизации 4f-люминесценции ионов $N d$ и Yb хромофором коррола отличается от такового в случае порфирина.
\end{abstract}

Ключевые слова: Корролы, порфирины, лантаниды, 4 -люминесценция, флуоресценция.

\section{Introduction}

Corolles are the closest structural analogues of wellknown macrocyclic tetrapyrrole compounds - porphyrins. Many derivatives of porphyrins and corroles are the basis of numerous natural compounds such as heme, vitamin
B12, etc. ${ }^{[1]}$ Corolles consist of completely unsaturated ring, and their main difference from porphyrins is the absence of one methine bridge between the pyrroles. Therefore, the number of carbon atoms in the aromatic chain changes and this macrocycle becomes tribasic (Figure 1). 

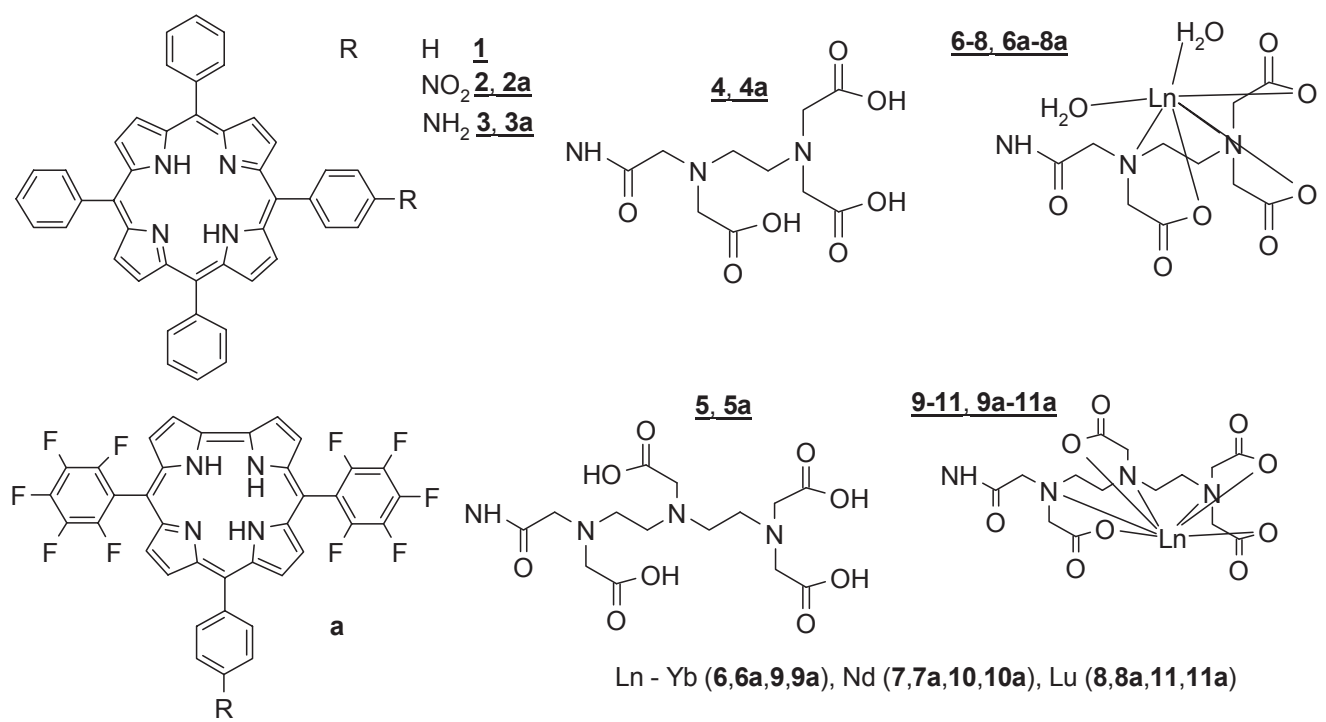

Ln - Yb (6,6a,9,9a), Nd (7,7a,10,10a), Lu (8,8a,11,11a)

Figure 1. Structure of porphyrins and corroles (number marked with a) studied.

Intensive study of corroles was started in 1999, when their one-step synthesis was discovered. ${ }^{[2]}$ Until that time corroles had obtained by complexed multi-step pathway, with a total yield of compounds (even the most simple structure) less than $0.1 \%{ }^{[3]}$

Both porphyrins and corroles already prove itself as efficient catalysts for oxidation ${ }^{[4]}$ and reduction reactions, ${ }^{[5]}$ as a basis for carbon monoxide sensors, ${ }^{[6]}$ as optodes for determination the $\mathrm{pH},{ }^{[7]}$ as ion-selective electrodes, ${ }^{[8]}$ as dyesensitized solar cells ${ }^{[9]}$ and also in medicine as fluorescent markers. ${ }^{[10]}$

Application of corroles in most cases is based on their fluorescent properties. These macrocycles have the characteristic absorption and emission of light (like porphyrins) due to 18 -membered aromatic $\pi$-systems. It should be noted that in comparison to porphyrins, corroles in some cases have an abnormally high fluorescence efficiency - a quantum yield of $76 \% .^{[11]}$

The present work describes a study of spectralluminescent properties of corroles and porphyrins and their complexes with $f$-metals. 5,10,15,20-tetraphenylporphyrin $\left(\mathrm{H}_{2} \mathrm{tpp}, \mathbf{1}\right)$ was used as a standard for the studied porphyrins, and 5,10,15-tris-(pentafluorophenyl)-corrole $\left(\mathrm{H}_{3} \mathrm{tpfc}, 12\right)$ was used as a standard for corroles. The choice of these standards based on their stability, their ease of preparation and their good scrutiny. In addition $\mathrm{H}_{2}$ tpp is a starting material in the synthesis of studied porphyrins and $\mathrm{H}_{3}$ tpfc is a close structural analogue of the studied corrole series.

\section{Experimental}

Synthesis of all porphyrins, corroles and their derivatives was performed accordingly to the known procedures. ${ }^{[12,13]}$ 5-(Pentafluorophenyl)-dipyrromethane (DPM) was synthesized accordingly to the reaction. ${ }^{[14]}$ Synthesis of $\mathrm{H}_{3}$ tpfc (12) was carried out according to the most convenient method for the preparation. ${ }^{[15]}$ Purity of the obtained compounds was checked by TLC Sorbfil plates (grain 5-17 $\mu \mathrm{m}, \mathrm{UV}-254$, thickness $0.1 \mathrm{~mm}$ ) by Imid Ltd. ${ }^{1} \mathrm{H}$ NMR and ${ }^{19} \mathrm{~F}$ NMR spectra were recorded using Bruker Avance
600 or $400 \mathrm{MHz}$ in $\mathrm{CDCl}_{3}$ and $\mathrm{CD}_{3} \mathrm{OD}$. Mass-spectra (MS) were registered on spectrometer Waters ESI TOF Premier and Varian MAT CH-112 spectrometer. Elemental analysis was performed on CHNS analyzer Flash 2000 Thermo Scientific.

Spectra of $4 f$-luminescence, molecular fluorescence and excitation spectra were recorded on spectrofluorimeter "Fluorolog FL 3-22" "Horiba Jobin Yvon" (Xe-lamp $450 \mathrm{~W}$ ). Spectra of 4 -luminescence of $\mathrm{Yb}^{3+}$ ions (transition ${ }^{2} \mathrm{~F}_{5 / 2} \rightarrow{ }^{2} \mathrm{~F}_{7 / 2}$ ) were registered at $950-1050 \mathrm{~nm}$ region and of $\mathrm{Nd}^{3+}$ at $850-1350$ nm (transitions ${ }^{4} \mathrm{~F}_{3 / 2} \rightarrow{ }^{4} \mathrm{I}_{13 / 2},{ }^{4} \mathrm{~F}_{3 / 2} \rightarrow{ }^{4} \mathrm{I}_{11 / 2}$ and ${ }^{4} \mathrm{~F}_{3 / 2} \rightarrow{ }^{4} \mathrm{I}_{9 / 2}$ ). Spectra of molecular fluorescence of porphyrins and corroles were registered at $550-800 \mathrm{~nm}$ (S-S transitions).

Luminescence integral intensity was measured using software of the device. Fluorescence lifetime $(\tau)$ was measured under excitation at the Soret band. The relative quantum yield of molecular fluorescence was determined using solution of Zn-tpp in ethanol as a primary reference. Determination of the relative quantum yield of molecular fluorescence and $4 f$-luminescence was made using formula:

$$
\varphi_{\mathrm{x}}=\varphi_{0} I_{\mathrm{x}} A_{0} \mathrm{n}_{\mathrm{x}}^{2} /\left(I_{0} A_{\mathrm{x}} \mathrm{n}_{0}^{2}\right),
$$

where: $\varphi_{0}$ and $\varphi_{\mathrm{x}}$ - luminescence quantum yield of the reference and of the sample respectively; $A_{0}$ and $A_{\mathrm{x}}$ - absorption at the Soret band of the reference and of the sample respectively; $I_{\mathrm{x}}$ and $I_{0}-$ integral luminescence intensity of the reference and of the sample respectively; $\mathrm{n}_{0}$ and $\mathrm{n}_{\mathrm{x}}$ - refractive index of the reference solvent and of the sample solvent respectively.

\section{Results and Discussion}

Synthesis of 10-(4-aminophenyl)-5,15-bis-(pentafluorophenyl)-corrole (3a), 5-(4-aminophenyl)-10,15,20triphenylporphyrin (3) and their further modification (Figure 1) was performed according to the previous works. ${ }^{[12-13]}$ It should be noted that the presence of fluorine atoms in corrole structure is desirable in terms of photo- and thermo stability of corroles. ${ }^{[16]}$

The step of formation of peripheral complexes on the base of ditopic ligands can not be administrated by absorption spectra in contrast to classical systems. Therefore, NMR and 
MS was used in this case. The formation of complexes with paramagnetic ions $\mathrm{Yb}^{3+}$ and $\mathrm{Nd}^{3+}$ can be fixed only by the methods ${ }^{19} \mathrm{~F}$ NMR and MS. Complexes with diamagnetic $\mathrm{Lu}^{3+}$ additionally can be identified with ${ }^{1} \mathrm{H}$ NMR. In the case of the latter, a linear NMR spectrum becomes extremely complicated in strong fields. Fragment of ${ }^{1} \mathrm{H}$ NMR spectrum reveals that the protons of the same methylene and ethylene groups are not equivalent due to a different location relative to the $\mathrm{Lu}^{3+}$ ion (Figure 2).

All signals in the aliphatic proton region $3.5-4.5 \mathrm{ppm}$ appear in the form of doublets, with the integrated intensity corresponding to one proton. High values of $J$ confirm that the spin-spin interaction constants are geminal $\left({ }^{2} J_{\mathrm{H}-\mathrm{H}}\right)$. Thus, signals at 4.34 and $4.15 \mathrm{ppm}$ have ${ }^{2} J=16.8 \mathrm{~Hz}$, signals at 3.96 and
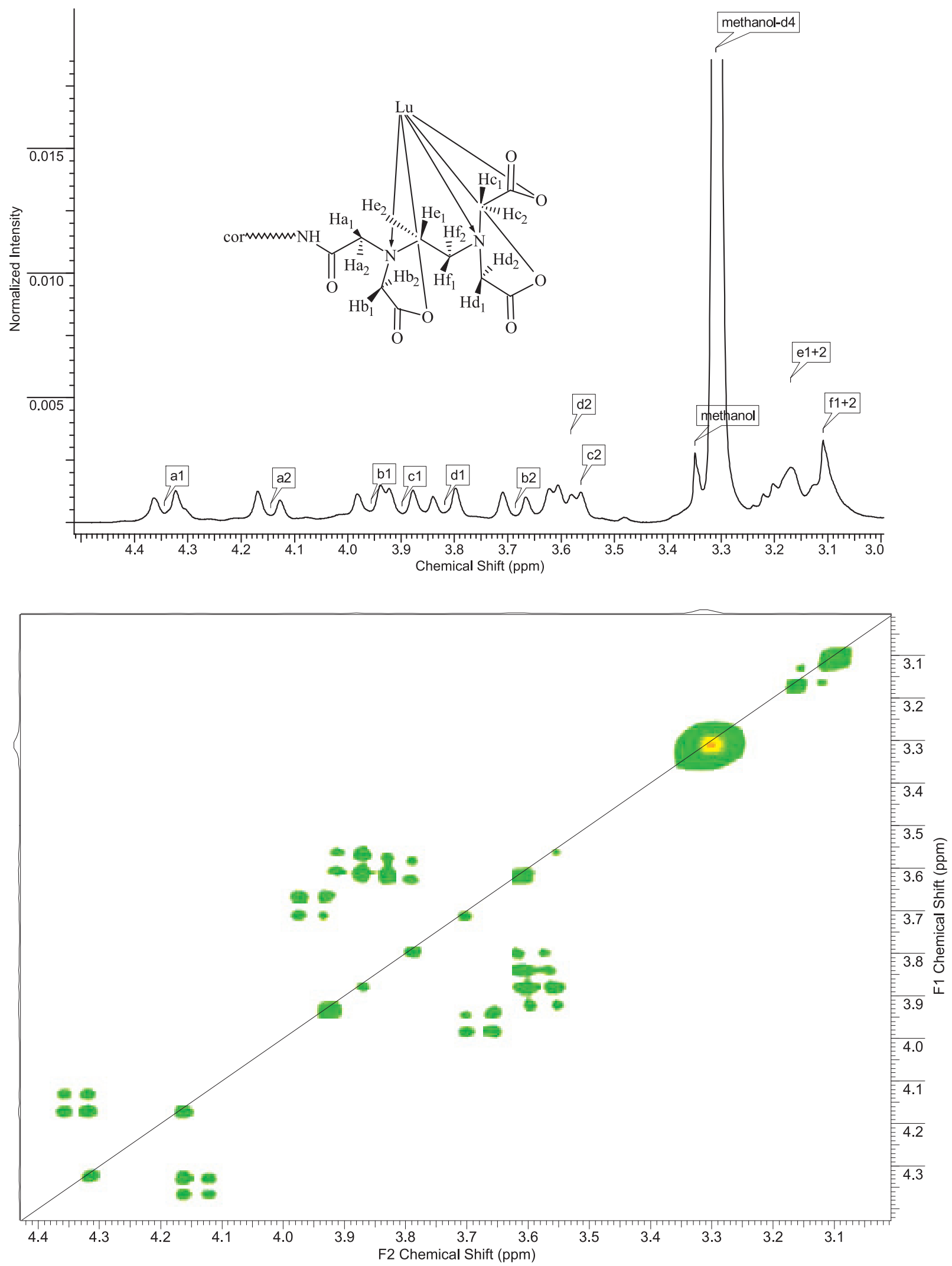

Figure 2. $1 \mathrm{D}{ }^{1} \mathrm{H}$ NMR (top) and $2 \mathrm{D}{ }^{1} \mathrm{H}$ NMR (bottom) spectra of 8 a. 
$3.69 \mathrm{ppm}$ have ${ }^{2} J=17.6 \mathrm{~Hz}$, signals at 3.90 and $3.58 \mathrm{ppm}$ have ${ }^{2} J=17.4 \mathrm{~Hz}$, signals at 3.82 and $3.60 \mathrm{ppm}$ have ${ }^{2} J=16.7 \mathrm{~Hz}$.

For identification of the aliphatic protons 2D COSY NMR method was also used. Four protons of ethylene groups have two broad signals. The multiplicity and position of each proton signal is difficult to determine, however, due to the appearance of appropriate cross-peaks, these signals are readily identified as an ethylene group protons.

The protons of the methylene groups were also able to identify, despite the overlapping of the signals. Most shifted downfield doublet at 4.34 and $4.15 \mathrm{ppm}$ correspond to the protons $\mathrm{H}^{\mathrm{a} 1}$ and $\mathrm{H}^{\mathrm{a} 2}$ near amide bond, doublets at 3.96 and 3.69 ppm are proton signals of carboxymethylene group $\mathrm{H}^{\mathrm{b} 1}$ and $\mathrm{H}^{\mathrm{b} 2}$. Couples $\mathrm{H}^{\mathrm{c} 1}$ and $\mathrm{H}^{\mathrm{c} 2}$ protons, $\mathrm{H}^{\mathrm{d} 1}$ and $\mathrm{H}^{\mathrm{d} 2}$ are equal in their surroundings, but due to the additional coordination of water molecules by lutetium ion (vide infra), they differ slightly in the position, and in the values of ${ }^{2} J_{\mathrm{H}-\mathrm{H}}$.

The absorption spectra of the porphyrins and corroles are characteristic and consist of intense Soret band in the region of 400-420 nm and four Q-bands in the region of 500$600 \mathrm{~nm}$ for porphyrins and two Q-bands in the region of 500$600 \mathrm{~nm}$ for corroles (Figure 3).

Absorption spectrum does not undergo significant changes under consequent modification of the starting $\mathrm{H}_{2}$ tpp to form the nitro derivative (2), the amino derivative (3) ditopic derivatives substituted with fragments of aminopolycarboxylic acids (APC) - ethylenediamine- $N, N, N$ ', $N$ 'tetraacetic ( $\left.\mathrm{H}_{4} \mathrm{EDTA}\right)$ acid (4) and diethylenetriamine$N, N, N$ ', $N$ ", $N$ "'-pentaacetic ( $\left.\mathrm{H}_{5} \mathrm{DTPA}\right)$ acid (5), as well as peripheral mononuclear metal complexes based on them (6-11). However, under modification of the substituent at para-position of the phenyl with APC resulting in formation of ditopic ligands $\mathbf{4}$ and $\mathbf{5}$, there is a slight bathochromic shift of the first absorption band (2-4 nm) in contrast to $\mathrm{H}_{2}$ tpp. This band is known ${ }^{[17]}$ to be the most sensitive to the structural changes in porphyrin. The optical density of all bands increases in the spectra of $\mathbf{4}$ and $\mathbf{5}$ in comparison to monotopic porphyrins.

The quantity of absorption bands, wavelengths of their maxima and molar absorption coefficients do not undergo significant change under the introduction of ions of heavy f-metals on the molecule periphery. Apparently, this fact is explained by a significant distance from the metal ion to the chromophore.

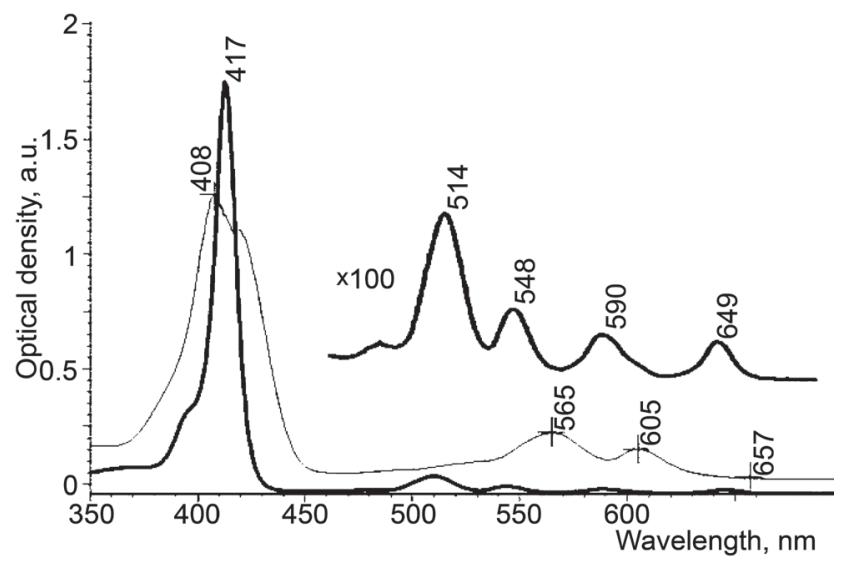

Figure 3. Absorption spectra of the $\mathrm{H}_{2} \operatorname{tpp}(\mathbf{1}$, bold line) and $\mathrm{H}_{3}$ tpfc (12, thin line).
In contrast to the porphyrins, a similar modification of para-aminophenyl derivative of corrole with APC fragments leads to a noticeable hypsochromic shift of the Soret band (Table 1). The remaining bands keep unchanged. The complexation of $f$-metal ions with the periphery of ditopic corrole is similar to porphyrins - there is no change in the absorption spectra in this case.

Table 1. Absorption spectra of the studied macrocyclic tetrapyrroles for solutions of 1-11 in DMF, 2a-11a and $\mathbf{1 2}$ in ethanol, $\lambda$, $\mathrm{nm}(\lg \varepsilon)$.

\begin{tabular}{cccccc}
\hline Sample & Soret & IV & III & II & I \\
\hline $\mathbf{1}$ & $417(5.1)$ & $514(3.7)$ & $548(3.3)$ & $590(3.1)$ & $649(3.1)$ \\
$\mathbf{3}$ & $419(5.28)$ & $517(4.08)$ & $558(3.99)$ & $592(3.72)$ & $652(3.71)$ \\
$\mathbf{4}$ & $419(5.57)$ & $514(4.36)$ & $551(4.15)$ & $593(3.93)$ & $648(3.93)$ \\
$\mathbf{5}$ & $418(5.60)$ & $515(4.30)$ & $552(4.11)$ & $591(3.91)$ & $650(3.91)$ \\
$\mathbf{6}$ & $419(5.56)$ & $515(4.36)$ & $550(4.16)$ & $591(4.05)$ & $648(4.03)$ \\
$\mathbf{7}$ & $419(5.46)$ & $515(4.31)$ & $550(4.17)$ & $591(4.08)$ & $648(4.05)$ \\
$\mathbf{8}$ & $419(5.49)$ & $515(4.32)$ & $550(4.11)$ & $591(4.05)$ & $648(4.02)$ \\
$\mathbf{9}$ & $418(5.53)$ & $514(4.37)$ & $551(4.19)$ & $592(4.03)$ & $647(4.04)$ \\
$\mathbf{1 0}$ & $418(5.54)$ & $514(4.32)$ & $551(4.17)$ & $592(4.04)$ & $647(4.01)$ \\
$\mathbf{1 1}$ & $418(5.53)$ & $514(4.35)$ & $551(4.19)$ & $592(4.03)$ & $647(4.04)$ \\
$\mathbf{2 a}$ & $412(5.08)$ & - & - & $568(4.38)$ & $615(4.26)$ \\
$\mathbf{3 a}$ & $415(5.08)$ & - & - & $568(4.38)$ & $615(4.26)$ \\
4a-11a & $410(5.08)$ & - & - & $568(4.38)$ & $615(4.26)$ \\
$\mathbf{1 2}$ & $408(5.08)$ & - & - & $565(4.25)$ & $605(4.02)$ \\
\hline
\end{tabular}

All of the compounds have intense molecular fluorescence in the region of $600-800 \mathrm{~nm}$. It should be noted that all of the investigated corroles do not show any phosphorescent properties. This fact is in accordance with the literature data and it is due to the rapid relaxation of triplet (T) levels in these macrocycles with the exception of some complex compounds, such as germanium-corroles, which phosphorescence was discovered for the first time recently. ${ }^{[18]}$

Molecular fluorescence of porphyrin appears as two Q-bands (0-0) in the region of 650-705 nm, and (0-1) 715-765 nm. Position of Q-bands in fluorescence spectra of mono-meso-amino derivative, as well as its APC-derivatives 4 and 5, are slightly different from the spectrum of the $\mathrm{H}_{2} \mathrm{tpp}$. This is probably due to the fact that the covalent bond in the porphyrin-modified systems is realized through the paraposition of the phenyl spacer, so in this case a steric factor does not play a significant role. At the same time it was found that the formation of modified porphyrins (through the phenyl spacer) leads to significant changes in $T_{1}$-states without affecting of lower singlet levels of macrocycle.

meso-(4-Phenyl) substitution of porphyrin with APC fragments, results (similarly to the absorption spectra) in a slight bathochromic (30-70 $\left.\mathrm{cm}^{-1}\right)$ and hypsochromic shifts of Q (0-0) band and does not affect (Table 2) the position of the excited singlet level $\left(E_{\mathrm{S} 1}=15270-15310 \mathrm{~cm}^{-1}\right)$. The Stokes shift increases slightly from $\mathrm{H}_{2}$ tpp to APC-modified ligands and it is $110-140 \mathrm{~cm}^{-1}$ (Tables 1 and 2), which is characteristic for porphyrins with asymmetric substitution on the phenyl ring. It should be noted that the substitution of $\mathrm{H}_{2}$ tpp reduces the molecular fluorescence quantum yield $\left(\varphi_{\mathrm{F}}\right)$. 
Phosphorescence spectra of free base porphyrins undergo a significant change in contrast to fluorescence spectra. Introduction of APC fragments leads to the hypsochromic shift (more than $450 \mathrm{~cm}^{-1}$ ) of phosphorescence band $0-0$, due to increase of triplet level energy $\left(E_{\mathrm{T} 1}=12060\right.$ $\left.12170 \mathrm{~cm}^{-1}\right)$. Further interaction with metal ions doesn't affect the phosphorescence characteristics.

Molecular fluorescence lifetime $\left(\tau_{\mathrm{S}}\right)$ decreases under modification of the $\mathrm{H}_{2}$ tpp. Moreover, the complexation reaction of the ditopic ligand periphery with metal ions $\mathrm{Yb}$ (III) and $\mathrm{Nd}(\mathrm{III})$ reduces this parameter intensively than $\mathrm{Lu}(\mathrm{III})$, due to the paramagnetic properties of lanthanide ions with unfilled $f$-shells, in contrast to the diamagnetic ion $\mathrm{Lu}$ (III).

From the other side, phosphorescence lifetime $\left(\tau_{\mathrm{p}}\right)$ reacts to the modification of the porphyrin as follows: the introduction of the amino group, the covalent binding fragments of APC and complexation reaction with lanthanide ions lead to its increase.

S-Levels of corroles are higher than those of the porphyrins because of the degradation of the symmetry from $D_{4 h}$ to $C_{2 v}$ in porphyrins and corroles, respectively. The $\tau_{\mathrm{S}}$ of corroles lower than $\tau_{\mathrm{s}}$ for all relevant porphyrins.

The energies of $\mathrm{T}_{1}$-levels of studied porphyrins (Table 2) consider them as potential $4 f$-luminescence sensitizers for lanthanide ions emitting in the near-infrared (IR) spectral range - such as $\mathrm{Yb}$ (III), $\mathrm{Nd}$ (III) and $\mathrm{Er}$ (III). It is known that their resonant levels are respectively equal to $10200 \mathrm{~cm}^{-1}$, $11500 \mathrm{~cm}^{-1}, 6500 \mathrm{~cm}^{-1}$, which enables them to act as acceptor energy levels from higher donor $\mathrm{T}_{1}$-levels of tetrapyrroles.

T-Corroles levels can not be determined due to the absence of phosphorescence in the metal-free compounds. ${ }^{[19]}$ Nonetheless, the values of their energy of some germanium complexes, ${ }^{[18]}$ gold, ${ }^{[20]}$ rhodium, ${ }^{[21]}$ iridium ${ }^{[22]}$ found that their $\mathrm{T}_{1}$-levels are also suitable for sensitizing $4 f$-luminescence.

Sensitization of $4 f$-luminescence of ytterbium and neodymium ions (coordinated by APC fragment) by porphyrin macrocycle is confirmed by the coincidence of the absorption spectrum of the complexes and excitation spectra of $4 f$-luminescence.

A distinctive feature of the peripheral lanthanide complexes is that $4 f$-luminescence appears without any affecting both the fluorescence and the phosphorescence of the porphyrin (Figure 4). 4f-Luminescence efficiency of $\mathrm{Yb}(\mathrm{III})$ and $\mathrm{Nd}(\mathrm{III})$ ions in all peripheral studied complexes is lower than for porphyrinates of these metals. This is easily explained by the lack of direct covalent interaction between the chromophore and the emitting ion. On the other hand the present approach for the creation of a lanthanide-porphyrin systems solves the stability issue for a practical application for example $\lg K($ Lu-EDTA $)=19.8 .^{[23]}$ In fact lanthanideporphyrins are relatively labile systems.

$4 f$-Emission efficiency of $\mathrm{Nd}$ ions in complexes with porphyrins is lower than that for $\mathrm{Yb}$ in isostructural complexes. This is due to the presence of several transitions from the resonance level of the neodymium ion $\left({ }^{4} \mathrm{~F}_{3 / 2} \rightarrow{ }^{4} \mathrm{I}_{13 / 2}\right.$, ${ }^{4} \mathrm{~F}_{3 / 2} \rightarrow{ }^{4} \mathrm{I}_{11 / 2}$ and ${ }^{4} \mathrm{~F}_{3 / 2} \rightarrow{ }^{4} \mathrm{I}_{9 / 2}$ ). From the other side ytterbium ion has only one transition $\left({ }^{2} \mathrm{~F}_{5 / 2} \rightarrow{ }^{2} \mathrm{~F}_{7 / 2}\right)$, therefore energy dissipation in this case is less probable.

$4 f$-Luminescence of $\mathrm{Yb}$ ion has a higher quantum yield in the dtpa-derivative of porphyrin than in edta-derivative. It can be explained with a greater saturation of the coordination number of lanthanide ion. The remaining coordination sites in edta-derivative is occupied by water molecules, which is confirmed for a similar derivative of corrole previously using MS technique. ${ }^{[12]}$ Further coordination of the solvent molecules by lanthanide ion results in a dissipation of energy due to overlapping of $4 f$-transitions bands with the vibrational quanta of $\mathrm{O}-\mathrm{H}$ - and $\mathrm{C}-\mathrm{H}$-bonds.

$4 f$-Luminescence sensitization by corrole chromophore confirmed by complete coincidence of the absorption spectra and $4 f$-luminescence excitation spectra of the corresponding complexes. However, obtained values of the 4 -luminescent characteristics are substantially different from complexes with porphyrins. Thus, the quantum yield

Table 2. Emission properties of corroles and porphyrins studied.

\begin{tabular}{|c|c|c|c|c|c|c|c|c|}
\hline & $E_{\mathrm{S} 1}, \mathrm{~cm}^{-1}$ & $\varphi_{\mathrm{F}}^{*}$ & $\tau_{\mathrm{s}}, \mathrm{ns}^{* *}$ & $\lambda_{\mathrm{P}}, \mathrm{nm}$ & $E_{\mathrm{T} 1}, \mathrm{~cm}^{-1}$ & $\tau_{\mathrm{p}}, \mathrm{ms}^{* * *}$ & $\varphi_{\mathrm{Nd}} \times 10^{4 *}$ & $\varphi_{\mathrm{Yb}} \times 10^{3 *}$ \\
\hline 1 & 15340 & 0.12 & 10.4 & 859 & 11640 & 5.1 & 2.4 & 4.8 \\
\hline 3 & 15310 & 0.11 & 9.80 & 862 & 11600 & 6.3 & & \\
\hline 4 & 15290 & 0.11 & 9.56 & 829 & 12060 & 12.8 & & \\
\hline 5 & 15270 & 0.11 & 9.94 & 822 & 12170 & 13.5 & & \\
\hline 6 & 15290 & 0.11 & 8.82 & 828 & 12070 & 12.9 & & 1.1 \\
\hline 7 & 15290 & 0.11 & 8.98 & 830 & 12050 & 12.6 & 2.0 & \\
\hline 8 & 15290 & 0.11 & 9.55 & 830 & 12050 & 12.4 & & \\
\hline 9 & 15270 & 0.11 & 9.01 & 823 & 12150 & 13.1 & & 1.5 \\
\hline 10 & 15270 & 0.11 & 9.04 & 820 & 12200 & 12.8 & 2.0 & \\
\hline 11 & 15290 & 0.11 & 9.79 & 821 & 12180 & 12.7 & & \\
\hline $3 \mathbf{a}$ & 15380 & 0.08 & 3.47 & & & & & \\
\hline $4 a$ & 15580 & 0.08 & 3.72 & & & & & \\
\hline $6 a$ & 15670 & 0.10 & 3.21 & & & & & $<0.1$ \\
\hline $7 \mathbf{a}$ & 15650 & 0.08 & 3.43 & & & & 27.9 & \\
\hline $9 a$ & 15630 & 0.09 & 3.57 & & & & & 0.3 \\
\hline $10 a$ & 15650 & 0.08 & 3.34 & & & & 14.4 & \\
\hline 12 & 15850 & 0.17 & 4.29 & & & & & \\
\hline
\end{tabular}

All solutions in DMF. $C=10^{-5} \mathrm{M} . * \pm 10 \%$; ** $\pm 0.02 \mathrm{~ns} ; * * * 77 \mathrm{~K}, \pm 0.02 \mathrm{~ns}$. 

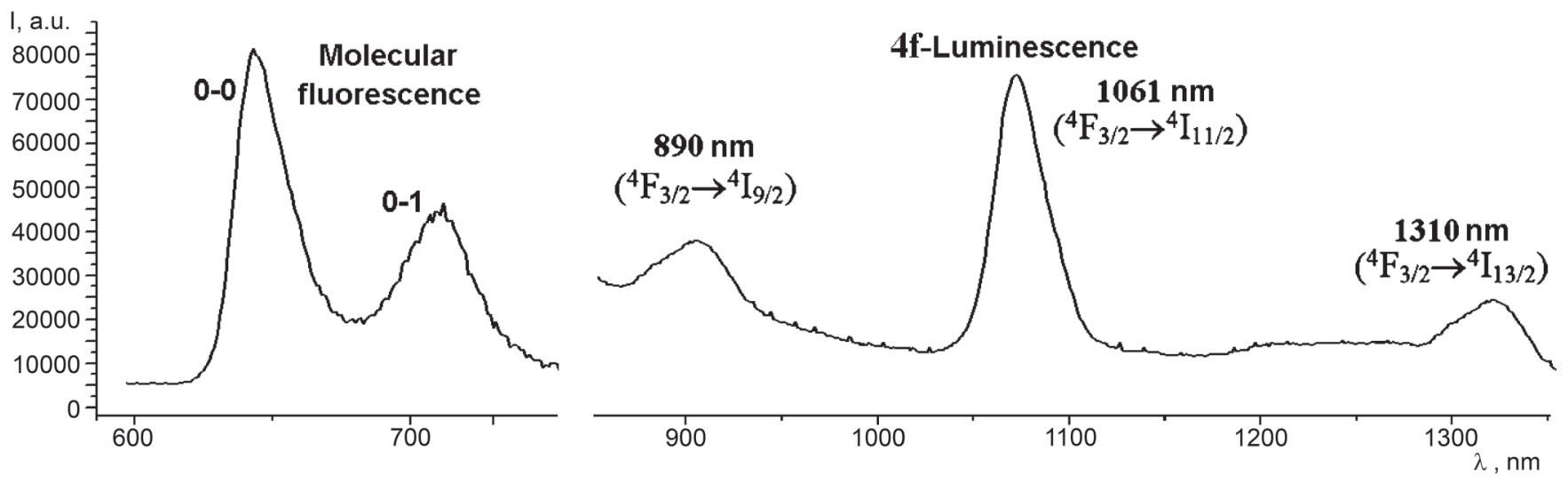

Figure 4. Emisson of $\mathbf{1 0}$ in two ranges.

of luminescence of neodymium complexes is much higher than for ytterbium complexes (Table 2). As it was mentioned above, according to the literature, ${ }^{[24]}$ the opposite pattern should be observed. Furthermore, in the case of compound $\mathbf{6 a}$, for example, a luminescent signal was so weak that calculation of $\varphi_{\mathrm{Yb}}$ was impossible.

Comparison of the effectiveness of neodymium emission in the complexes shows that $\varphi_{\mathrm{Nd}}$ in corroles is an order of magnitude higher than in porphyrins. Apparently, these facts suggest an alternative way of excitation energy transfer in corrole-lanthanides - the excitation energy is transferred directly from the $\mathrm{S}_{1}$-level of corrole.

Currently, it can be assumed that the sensitization passes through two transitions: the traditional $\mathrm{T}_{1} \rightarrow{ }^{4} \mathrm{~F}_{3 / 2}$, and $\mathrm{S}_{1} \rightarrow{ }^{4} \mathrm{~F}_{3 / 2}$.

Such a mechanism may be well realized due to the effective overlap of the 0-0 and 0-1 molecular fluorescence bands of corrole and $f-f$ transitions of $\mathrm{Nd}$ (III) ion.

Note, that as in the case of porphyrins, $4 f$-luminescence in corrole derivatives appears without any affecting the fluorescence characteristics of the corrole, but the phosphorescence is still absent.

\section{Conclusions}

Thus, we analized the structure of peripheral lanthanide complexes based on ditopic corroles and porphyrins using NMR and MS techniques. We compared such fluorescence and $4 f$-luminescence features of corrole-based and porphyrinbased lanthanide systems, as quantum yield, luminescence lifetime, and energy levels. Finally, obtained results show that sensitization mechanism of luminescence of $\mathrm{Nd}$ and $\mathrm{Yb}$ ions has different pathways in corrole systems. Porphyrin derivatives have three types of emission, from the other side corrole derivatives have only two types of emisson.

\section{References}

1. Zipp C.F., Michael J.P., Fernandes M.A., Mathura S., Perry C.B., Navizet I., Govender P.P., Marques H.M. Inorg. Chem. 2014, 53, 4418-4429.
2. Gross Z., Galili N., Saltsman I. Angew. Chem., Int. Ed. 1999, 38, 1427-1429.

3. Johnson A.W., Price R. J. Chem. Soc. (Resumed) 1960, 16491653.

4. Liu H.-Y., Lai T.-S., Yeung L.-L., Chang C. K. Org. Lett. 2003, 5, 617-620.

5. Grodkowski J., Neta P., Fujita E., Mahammed A., Simkhovich L., Gross Z. J. Phys. Chem. A 2002, 106, 4772-4778.

6. Barbe J.-M., Canard G., Brandes S., Jerome F., Dubois G., Guilard R. Dalton Trans. 2004, 8, 1208-1214.

7. Li C.-Y., Zhang X.-B., Han Z.-X., Akermark B., Sun L., Shen G.-L., Yu R.-Q. Analyst 2006, 131, 388-393.

8. Radecki J., Stenka I., Dolusic E., Dehaen W. Electrochim. Acta 2006, 51, 2282-2288.

9. Walker D., Chappel S., Mahammed A., Brunschwig B.S., Winkler J.R., Gray H.B., Zaban A., Gross Z. J. Porphyrins Phthalocyanines 2006, 10, 1259-1262.

10. Agadjanian H., Weaver J., Mahammed A., Rentsendorj A., Bass S., Kim J., Dmochowski I., Margalit R., Gray H., Gross Z., Medina-Kauwe L. Pharm. Res. 2006, 23, 367-377.

11. Mahammed A., Gross Z. J. Inorg. Biochem. 2002, 88, 305-309.

12. Semenishyn N., Gross Z. Dalton Trans. 2013, 42, 3775-3778.

13. Rusakova N., Semenishyn N., Korovin Yu. J. Porphyrins Phthalocyanines 2010, 14, 166-169.

14. Laha J.K., Dhanalekshmi S., Taniguchi M., Ambroise A., Lindsey J.S. Org. Process Res. Dev. 2003, 7, 799-812.

15. Reith L.M., Stiftinger M., Monkowius U., Knör G., Schoefberger W. Inorg. Chem. 2011, 50, 6788-6797.

16. Geier G.R., Chick J.F.B., Callinan J.B., Reid C.G., Auguscinski W.P. J. Org. Chem. 2004, 69, 4159-4169.

17. Takeda J., Ohya T., Sato M. Chem. Phys. Lett. 1991, 183, 384-386.

18. Nardis S., Mandoj F., Paolesse R., Fronczek F.R., Smith K.M., Prodi L., Montalti M., Battistini G. Eur. J. Inorg. Chem. 2007, 2007, 2345-2352.

19. Ventura B., Degli Esposti A., Koszarna B., Gryko D.T., Flamigni L. New J. Chem. 2005, 29, 1559-1566.

20. Rabinovich. E., Goldberg I., Gross Z. Chem.-Eur. J. 2011, 17, 12294-12301.

21. Tanabe M., Matsuoka H., Ohba Y., Yamauchi S., Sugisaki K., Toyota K., Sato K., Takui T., Goldberg I., Saltsman I., Gross Z. J. Phys. Chem. A 2012, 116, 9662-9673.

22. Palmer J.H., Durrell A.C., Gross Z., Winkler J.R., Gray H.B. J. Am. Chem. Soc. 2010, 132, 9230-9231.

23. Alexander V. Chem. Rev. 1995, 95, 273-342.

24. Oude Wolbers M.P., van Veggel F.C.J.M., Snellink-Ruel B.H.M., Hofstraat J.W., Geurts F.A.J., Reinhoudt D.N. J. Chem. Soc., Perkin Trans. 2 1998, 10, 2141-2150.

Received 28.04.2016

Accepted 13.06.2016 